\title{
PENGARUH SERTIFIKASI GURU TERHADAP PROFESIONALISME, PENGEMBANGAN DIRIBERKELANJUTAN DAN KEPUASAN KINERJA GURU IPS MAN Se Kota MALANG PASCASERTIFIKASI
}

\author{
Ni'matuz Zuhroh \\ UIN Maulana Malik Ibrahim Malang
}

\begin{abstract}
This study aims to determine the effect of Teacher Certification on Professionalism, Sustainable Self Development, and Job Satisfaction Teachers IPS MAN Malang PostCertification. This study uses a quantitative approach and data taken by means of crosssection data collected at the same time from many subjects and retrieval of this data is only done once. In this research the data collection method used is by using questionnaire (questionnaire) that is given to all teachers IPS MAN Se Malang city that has been certified. Primary data taken are data about teacher professionalism, ongoing self-development and job satisfaction. While the questionnaire about teacher performance is filled by the Principal. Other secondary data is the number of teachers who have certification / teacher identity already certified. Measurement scale for primary data by using Likert Scale. Testing data used validity and reliability test. The result of this research is that Teacher Certification to Professionalism, Self Development and Work Satisfaction of Teacher IPS MAN Malang Post Certification ". Influence significantly.
\end{abstract}

Keywords: Teacher Certification, Professionalism, Self-sustained Development and Performance Satisfaction

\section{Pendahuluan}

Tantangan dan tuntutan adanya sumber daya manusia yang berkualitas, bermuara pada pelaksanaan pendidikan yang bermutu. Peningkatan mutu pendidikan diarahkan untuk meningkatkan kualitas manusia Indonesia seutuhnya melalui olah hati, olah pikir, olah rasa dan olahraga memiliki daya saing dalam menghadapi tantangan global. ( Yamin dan Maisah 2010:26). Dampak adanya tuntutan pendidikan yang bermutu, maka lembaga pendidikan harus selalu berupaya memberikan penjaminan mutu kepada pihak-pihak yang berkepentingan ( stakeholder) dengan melakukan pemenuhan standar nasional pendidikan yang sudah ditentukan yaitu mulai, dari standar isi, proses, kompetensi lulusan, pendidik, tenaga kependidikan, sarana dan prasarana, pengelolaan, pembiayaan yang telah ditetapkan. Pemenuhan standar pendidikan dimaksudkan agar tujuan pendidikan secara nasional dapat tercapai. 
Berbagai usaha dilakukan oleh pemerintah untuk lebih memantapkan peran guru dalam dunia pendidikan. Salah satunya adalah dengan melaksanakan program sertifikasi. Peraturan Peraturan Pemerintah Republik Indonesia nomor 74 tahun 2008 tentang guru disebutkan dalam pasal 1 ayat 2 dan 3, sertifikasi adalah " proses pemberian sertifikat pendidik untuk guru, sertifikat pendidik adalah bukti formal sebagai pengakuan yang diberikan kepada guru sebagai tenaga profesional". Menurut Wibowo ( dalam Mulyasa, 2011:35) “ Sertifikasi bertujuan untuk, (1) melindungi profesi pendidik dan tenaga kependidikan, (2) melindungi masyarakat dari praktikpraktik yang tidak kompeten, sehingga merusak citra pendidik dan tenaga kependidikan, (3) membantu dan melindungi lembaga penyelenggara pendidikan, dengan menyediakan rambu-rambu dan instrumen untuk melakukan seleksi terhadap pelamar yang kompeten, (4) membangun citra masyarakat terhadap profesi pendidik dan tenaga kependidikan, (5) memberikan solusi dalam rangkah meningkatkan mutu pendidik dan tenaga kependidikan".Pada umumnya rasional untuk menerapkan sertifikasi guru menurut Sykes ( dalam Sukamto, 2009:5) adalah untuk:

(1) Melindungi masyarakat dalam hal ini para siswa dari bahaya perilaku guru yang tidak kompeten, (2) Menjamin pembakuan standar antar daerah secara nasional, sehingga menjamin juga adanya keadilan (fairness) di kalangan masyarakat, (3) untuk menjamin kepentingan negara bagian dalam mendidik warganya, karena hasil pendidikan ini sangatlah penting untuk negara bagian yang bersangkutan sehingga mereka punya interest yang besar terhadap pencapaian hasil pendidikan yang kualitasnya merata.

Tentang guru yang profesional Yamin (2009:6) menyatakan:

Seorang guru yang profesional adalah Dia yang memiliki keahlian, ketrampilan dan kemampuan sebagaimana filosofi Ki hajar Dewantoro “ Ing ngarso sung tulodho, Ing madyo mangun karso dan tut wuri handayani”, Tidak cukup hanya menguasai materi pelajaran akan tetapi mengayomi murid, memberi contoh atau teladan bagi murid serta mendorong murid untuk lebih maju. Guru Profesional selalu mengembangkan dirinya terhadap pengetahuan dan mendalami keahliannya, kemudian guru profesional rajin membaca literatur-literatur dengan tidak merasa rugi membeli buku-buku yang berkaitan dengan pengetahuan yang digelutinya. Guru profesional juga memiliki kompetensi yang memadai. 
Apabila guru memiliki kompetensi yang memadai dalam proses pembelajaran maka kompetensi lulusan juga menjadi baik, Menurut ( Payong :2011:82) “ rendahnya kemampuan siswa dapat diduga juga berasal dari rendahnya mutu proses pembelajaran yang di selenggarakan di sekolah dimana guru sebagai faktor kuncinya. Karena itu selain faktor-faktor siswa dan faktor lainnya guru patut diduga memberikan andil bagi rendahnya prestasi siswa ini," karena produk guru adalah prestasi para siswa-siswi dan lulusannya dari sesuatu sekolah, lulusan tersebut harus mampu bersaing dalam dunia akademisi dan dunia kerja yang tidak lain berfokus pada mutu'( Yamin dan Maisah, 2009:28). Dalam kajian ini lebih difokuskan pada Guru IPS MAN Se Kota Malang Pascasertifikasi.

\section{PROFESIONALISME GURU}

Sejak ditetapkannya jabatan guru sebagai profesi, maka kegiatan yang berhubungan dengan kualitas guru menjadi perhatian oleh semua pihak. Dampak adanya jabatan guru sebagai profesi, maka guru dituntut untuk berlaku secara profesional. (Sukamto, 2009:5). “ Profesi guru mungkin merupakan suatu profesi yang dalam kesehariannya harus menghadapi berbagai persoalan pengambilan keputusan secara profesional", Guru perlu mempunyai komitmen yang tinggi dalam melaksanakan kegiatan profesionalny. Menurut saudagar (2009:95) 'Perilaku pendidik yang profesionalnya dilandasi oleh nilai-nilai moral etika profesi”, Alma menegaskan( 2009:132) “ guru profesional dituntut memiliki kode etik yaitu norma tertentu sebagai pegangan yang diakui serta dihargai oleh masyarakat.

Profesionalisme guru selalu dihubungkan dengan profesi yang disandang oleh guru. Menurut Saudagar (2009:6). Profesionalisme guru adalah sikap seseorang profesional yang menjunjung tinggi kemampuan profesinya, ia akan bekerja dan mengerjakan sesuatu sesuai dengan bidangnya. Sedangkan Alma (2009:136) menyatakan Profesional berarti produk dan kadar. Ini mengacu pada sikap para anggota profesi terhadap profesinya dalam hal pengetahuan dan keahlian dalam melakukan pekerjaan". Profesionalisme guru maksudnya sama dengan guru profesional. Menurut Yamin dan Maisah (2010:28) guru profesional adalah guru yang mengedepankan mutuh dan kualitas layanan dan produknya, layanan guru harus memenuhi standarisasi kebutuhan masyarakat, bangsa dan pengguna serta 
memaksimalkan kemampuan peserta didik berdasarkan pada potensi dan kecakapan yang dimiliki oleh masing-masing individu". Mahsunah dkk (2012:10) dalam melaksanakan tugas pokok dan fungsinya bersifat otonom, menguasai kompetensi secara komprehensif dan daya intelektual tinggi. Dari pengertian diatas, maka dapat disimpulkan bahwa profesionalitas guru adalah sikap guru profesional sesuai dengan keahliannya yang mengedepankan kualitas layanan.

- Kualitas profesional Guru

Dalam dunia kerja diperlukan etos kerja yang profesional. Hal ini disebabkan karena dengan adanya etos kerja yang baik, maka diharapkan kinerjanya juga menjadi lebih baik. Menurut Danim ( dalam Mahsunah, 2012:76) secara akademik guru profesional bercirikan sebagai berikut:

1. Mumpuni kemampuan profesionalnya dan siap diuji atas kemampuannya.

2. Memiliki kemampuan berintegrasi antar guru dan kelompok lain yang "seprofesi" dengan mereka melalui kontrak dan aliran sosial.

3. Melepaskan diri dari belenggu kekuasaan birokrasi, tanpa menghilangkan etika kerja dan tata santun berhubungan dengan atasannya.

4. Memiliki rencana dan program pribadi untuk meningkatkan kompetensi dan gemar melibatkan diri secara individual atau kelompok seminar untuk merangsang pertumbuhan.

5. Berani dan mampu memberikan masukan kepada semua pihak dalam rangkah perbaikan mutu pendidikan dan pembelajaran termasuk dalam penyusunan kebijakan bidang pendidikan.

6. Siap bekerja secara tanpa diatur, karena sudah bisa mengatur dan mendisiplinkan dirinya.

7. Siap bekerja tanpa diseru atau diancam, karena sudah bisa memotivasi dengan mengatur dirinya.

8. Secara rutin melakukan evaluasi diri untuk mendapatkan umpan balik demi perbaikan diri.

9. Memiliki empati yang kuat.

10. Mampu berkomunikasi secara efektif dengan siswa, kolega, komunitas sekolah dan masyarakat.

11. Menjunjung tinggi etika kerja dan kaidah hubungan kerja

12. Menjunjung tinggi kode etik organisasi temptanya bernaung 
13. Memiliki kesetiaan ( loyality) dan kepercayaan (trust) dalam makna tersebut mengakui keterkaitannya dengan orang lain dan tidak mementingkan dirinya sendiri.

14. Adanya kebebasan diri dalam beraktualisasi melalui kegiatan lembagalembaga sosial dengan berbagai ragam perspektif.

\section{PENGEMBANGAN DIRI BERKELANJUTAN}

Menjadi suatu keharusan bagi seorang guru untuk selalu mengembangkan diri. Menurut Mahsunah dkk (2012:8) “selama menjalankan tugas-tugas profesional, guru dituntut melakukan profesionalisasi atau proses penumbuhan dan pengembangan profesinya. Diperlukan upaya terus-menerus agar guru tetap memiliki pengetahuan dan ketrampilan yang sesuai dengan tuntutan kurikulum serta kemajuan IPTEK", Arifin (dalam Purwanto dkk, 2011:45) ada beberapa hal yang perlu diperhatikan oleh setiap guru dalam upaya pengembangan kualitas diri sebagai guru yang kompeten dan profesional. Hal ini bertujuan untuk selalu eksis dalam perkembangan ilmu pengetahuan dan teknologi”.

Pengembangan diri berkelanjutan atau Continuing Development akhir-akhir ini ramai dibicarakan.Hal ini disebabkan karena guru setelah mendapatkan sertifikat pendidik mempunyai kewajiban untuk meningkatkan kualitas profesionalnya dengan melaksanakan pengembangan diri berkelanjutan. Aqib dan Rahmanto (2008:147) “ Pengembangan profesi guru melalui pendidikan guru yang lebih berorientasi pada pengembangan kepribadian dan profesi dalam satu lembaga pendidikan guru yang terpadu".

Konferensi pendidikan Internasional UNESCO di Jenewa ( Goble dalam Saud,2010:126) mengatakan " Pemantapan pendidikan guru lanjutan (continuing and inservice education and training) yang diperlukan di semua jenjang/tingkatan sistem, sejak pendirian primer ( di jenjang dasar) hingga pendidikan tersier ( di jenjang perguruan tinggi) termasuk pendidikan bagi orang dewasa harus didukung oleh banyak usaha pejabat yang berwenang di bidang usaha semacam itu mencakup analisis kuantitatif mengenai pengadaan ( penyiapan) dan kebutuhan guru ( tenaga kependidikan) di suatu negara dan juga pelaksanaan perencanaan nasional atau regional (wilayah/daerah) pendidikan lanjutan bagi para guru-guru ( tenaga kependidikan)". Orientasi utama pembinaan profesionalisme guru adalah membina 
agar menjadi " pembelajar sepanjang hayat" (life long learners)" Hidayatullah,2009:35). Saud (2010:120) mengatakan :

Pengembangan profesi keguruan bukan hanya memerlukan dukungan program pengembangan yang bersifat luwes yang dapat memberikan peluang setiap pengemban profesi guru itu menempuhnya secara luwes melalui prosedur yang bersifat multientry dan atau lintas jalur jenis kategori bidang keahlian, juga paket-paket programnya seyogyanya dikembangkan secara luwes pula sehingga memberikan peluang kemudahan prosedural dan juga memberikan dorongan yang menggairakan guru untuk melakukan upaya pengembangan keprofesiannya secara berkelanjutan dengan cara yang lebih variasi.

- Aspek-aspek dalam pengembangan diri berkelanjutan.

Ada aturan dan beberapa ahli yang mengungkapkan tentang aspek-aspek yang ada dalam pengembangan diri berkelanjutan, antara lain menurut UU no 16 tahun 2009, ada 3 aspek yang ada dalam pengembangan keprofesian berkelanjutan guru yaitu: (1) melaksanakan pengembangan diri, (2) melaksanakan publikasi ilmiah, (3) melaksanakan karya inovatif. Adapun untuk pengembangan diri berkelanjutan aspeknya adalah (a) mengikuti diklat fungsional, (b) kegiatan kolektif guru yang meningkatkan kompetensi atau keprofesian guru. Sedangkan payong (2011:19) mengemukakan:

Bahwa bentuk-bentuk pengembangan profesional berkelanjutan dapat dilakukan secara individual melalui inisiatif guru untuk mengembangkan diri, mengembangkan kompetensi keilmuannya, melakukan refleksi dan penelitianpenelitian tindakan kelas, membaca jurnal-jurnal ilmiah, memperluas jaringan kerja, meningkatkan koleksi perpustakaan pribadi dan lain-lain. Sebaliknya pengembangan profesional berkelanjutan dapat juga dilakukan secara institusional atas inisiatif dari Kepala Sekolah atau otoritas pendidikan terkait, misalnya melalui perkumpulan dalam wadah-wadah guru seperti KKG, MGMP,K3S dan MKKS.

Dalam rangka pengembangan profesionalisme tenaga pendidik, ada beberapa maksud yang ingin dicapai. Menurut Sudarwan dalam Saudagar dan Idrus (2009:99) “ pengembangan profesional tenaga pendidik dimaksudkan untuk memenuhi tiga kebutuhan, pertama, kebutuhan sosial untuk 
meningkatkan kemampuan sistem pendidikan yang efisien dan manusiawi serta melakukan adaptasi untuk menyusun kebutuhan-kebutuhan sosial. Kedua, kebutuhan untuk menemukan cara-cara untuk membantu staf pendidikan dalam rangka mengembangkan pribadinya secara luas. Ketiga, kebutuhan untuk mengembangkan dan mendorong keinginan tenaga pendidik untuk menikmati dan mendorong keinginan pribadinya, seperti halnya dia membantu peserta didiknya dalam rangka mengembangkan keinginan dan keyakinan untuk memenuhi tuntutan pribadi yang sesuai dengan potensi dasarnya. Yang memberikan dukungan melalui penyediaan sarana, fasilitas dan bahkan dana yang memadai.

\section{KEPUASAN KERJA}

Seperti yang dikatakan Sopiah (2008:170):

(1) Kepuasan kerja merupakan suatu tanggapan emosional seseorang terhadap situasi kerja dan kondisi kerja, (2) tanggapan emosional bisa berupa perasaan puas ( positif) atau tidak puas (negatif). Bila secara emosional puas berarti kepuasan kerja tercapai dan sebaliknya bila tidak maka berarti karyawan tidak puas, (3) kepuasan kerja dirasakan karyawan setelah karyawan tersebut membandingkan antara apa yang dia harapkan akan dia peroleh dari hasil kerjanya dengan apa yang sebenarnya dia peroleh dari hasil kerjanya.

Dalam menjalankan tugasnya seorang guru dapat dilihat kepuasan kerjanya dengan mengamati pada kesenangan dalam menjalankan tugas. Cherington ( dalam Johan, 2008: 8) “ Kepuasan kerja pada dasarnya merujuk pada seberapa besar seseorang pegawai menyukai pekerjaannya". Sedangkan Robbin dan Judge (2007:107) mendefinisikan “ Kepuasan Kerja sebagai suatu perasaan positif tentang pekerjaan seseorang yang merupakan hasil dari sebuah evaluasi karakteristiknya.

- Faktor-faktor yang mempengaruhi kepuasan kerja.

Ada beberapa faktor yang mempengaruhi kepuasan kerja seseorang. Menurut Luthan (2006:244-246) mengatakan : “Faktor- faktor yang mempengaruhi kepuasan adalah (1). Pekerjaan itu sendiri. Kepuasan Pekerjaan itu sendiri merupakan sumber utama kepuasan. (2) Gaji, upah atau gaji dikenal menjadi signifikasi dan merupakan faktor multidimensi dalam kepuasan kerja.(3) promosi,kesempatan promosi memiliki 
pengaruh yang berbeda dalam kepuasan kerja hal ini karena promosi memiliki sejumlah bentuk yang berbeda dan berfungsi sebagai penghargaan. (4) pengawasan, Pengawasan menjadi sumber penting dalam kepuasan kerja, (5) Kelompok Kerja, rekan kerja atau anggota tim yang kooperatif merupakan sumber kepuasan yang paling sederhana pada karyawan secara individu,(6) kondisi Kerja, Kondisi kerja memiliki pengaruh terhadap kepuasan kerja. Jika kondisi kerja bagus, bersih, lingkungan menarik, individu akan lebih mudah menyelesaikan tugas mereka”. Lebih lanjut Hariandja ( 2002:291) mengatakan bahwa “ Kepuasan kerja seseorang dipengaruhi oleh banyak faktor, tidak hanya gaji, tetapi terkait dengan pekerjaan itu sendiri, dengan faktor lain seperti hubungan atasan dengan bawahan, rekan kerja, lingkungan kerja dan aturan-aturan.

Faktor-faktor penyebab kepuasan kerja adalah (a) bekerja pada tempat yang tepat, (b) pembayaran yang sesuai, (c) organisasi dan manajemen, (d) Supervisi pada pekerjaan yang tepat, (e) orang yang berada dalam pekerjaan yang tepat." Berdasarkan pengetahuan terbaru, pedoman ini mungkin membantu meningkatkan kepuasan kerja, yaitu (1) membuat pekerjaan yang lebih menyenangkan, (2) memiliki gaji, benefit dan kesempatan promosi yang adil, (3) menyesuaikan orang pekerjaan yang sesuai dengan minat dan keahlian mereka, (4) mendesain pekerjaan agar menarik dan menyenangkan”. ( luthan, 2006:247-248). Sopiah ( 2008:172) menegaskan bahwa aspek-aspek yang berpengaruh terhadap kepuasan kerja adalah (1) promosi, (2) gaji,(3) pekerjaan iutu sendiri, (4) Supervisi, (5) teman kerja, (6) keamanan kerja, (7) kondisi kerja ( administrasi/ kebijakan perusahaan) (8) komunikasi, (9) tanggungjawab, (10) pengakuan, (11) prestasi kerja (12) kesempatan untuk berkembang.

- Pengukuran Kepuasan Kerja.

Kepuasan kerja seseorang Termasuk guru memang sulit untuk diukur, namun ada hal tersebut dapat diusahakan. Sopiah (2008:175) menyatakan ada beberapa cara mengukur kepuasan kerja, diantaranya (1) menggunakan skala indeks deskripsi jabatan ( job description index), (2) dengan menggunakan kuesioner kepuasan kerja Minnesota ( Minnesota Satisfaction Questionare),(3) Pengukuran berdasarkan ekspresi wajah ( Mangkunegara). 


\section{KINERJA GURU}

Dalam rangka peningkatan kualitas sumberdaya manusia, maka peningkatan dalam jalur pendidikan menjadi solusi yang tepat. Baedhowi (2009:90) kunci untuk merubah nasib suatu bangsa adalah pendidikan, dan kunci pembangunan pendidikan adalah guru. Untuk itulah kinerja guru perlu mendapat perhatian yang serius”. Menurut Yamin dan Maisah (2009:87) “ tenaga pengajar dengan kinerjanya adalah menyangkut seluruh aktifitas yang ditunjukkan oleh tenaga pengajar dan tanggung jawab untuk mendidik, mengajar, membimbing, mengarahkan dan memandu peserta didik dalam rangka menggiring perkembangan peserta didik ke arah kedewasaan mental- spiritual maupun fisik-biologis “. Mahsunah dkk (2012:11) mengatakan, berdasarkan penilaian kinerja juga akan diketahui tentang kekuatan dan kelemahan guru-guru sesuai dengan tugasnya masing-masing, baik guru kelas, guru bidang studi maupun guru bimbingan konseling”. Hasil kajian yang dilakukan Tim Direktorat Jenderal PMPTK tahun 2008 menunjukkan bahwa peningkatan kinerja guru yang tercermin dalam keempat kompensasi, guru yang telah lulus sertifikasi, baik melalui penilaian portofolio maupun PLPG belum menunjukkan peningkatan yang signifikan, meskipun secara umum peningkatan kompetensi guru yang lulus sertifikasi melalui penilaian portofolio ( Baedhowi, 2009:21). Kenyataan ini menunjukkan bahwa sertifikasi saja tidaklah cukup sebagai upaya mewujudkan dan meningkatkan kompetensi guru, meskipun guru sudah dinyatakan lulus sertifikasi dan bahkan telah menerima tunjangan profesi bukan berarti mereka telah memiliki kompetensi yang dusyaratkan oleh undang-undang.

Pasal 1 ayat 8 ( UU No.16 tahun 2009); Penilaian kinerja guru adalah penilaian dari tiap butir kegiatan tugas utama guru dalam rangka pembinaan karier kepangkatan dan jabatannya”. Moeheriono (2010:61), mengatakan kinerja atau performance atau hasil kerja yang dapat dicapai oleh seseorang atau sekelompok orang dalam suatu organisasi baik secara kuantitatif maupun kualitatif sesuai dengan kewenangan dan tugas tanggung jawab masing-masing dalam upaya mencapai tujuan organisasi bersangkutan secara legal tidak melanggar hukum dan sesuai dengan moral maupun etika." Lebih lanjut Mangkupra wiro dan Vitayala (dalam Yamin dan Maisah, 2010:87) menegaskan tenaga pengajar dengan kinerjanya adalah menyangkut seluruh aktifitas yang ditunjukkan oleh tenaga pengajar dalam tanggung jawabnya sebagai orang yang mengemban suatu amanat dan tanggungjawab untuk mendidik, mengajar, 
membimbing, mengarahkan dan memandu peserta didik dalam rangka menggiring perkembangan peserta didik kearah kedewasaan mental spiritual maupun fisik biologis. Menurut Mahsunah dkk (2012:11)" Penilaian kerja dimaksudkan untuk mengetahui kemampuan guru yang sebenarnya dalam melaksanakan pembelajaran.

\section{METODE PENELITIAN}

Penelitian ini menggunakan pendekatan kuantitatif dan data yang diambil dengan cara cross-section yaitu data yang dikumpulkan pada waktu yang bersamaan dari banyak subyek dan pengambilan data ini hanya dilakukan sekali. Jenis data ada 2 yaitu data primer dan data sekunder. Data primer diambil dengan menggunakan angket ( kuesioner) dan data sekunder dengan mengambil dari dokumen yang ada pada Sekolah yaitu MAN Se Kota Malang.Populasi dalam penelitian ini adalah semua guru IPS MAN Se kota Malang yang sudah tersertifikasi, dengan menggunakan Survai, sedangkan Unit Analisis, dalam penelitian ini yang dipergunakan adalah individu, yaitu para guru IPS MAN Se Kota Malang yang sudah sertifikasi sebagai responden. Penelitian ini memperlakukan responden secara alamiah, yaitu tanpa bentuk intervensi atau perlakuan apapun atau mereka berada pada situasi riil apa adanya.Pengembangan Instrumen Penelitian.Sebelum membuat instrumen penelitian, peneliti mengambil beberapa indikator dari variabel yang diteliti dan sudah dibuat berdasarkan pendapat beberapa ahli. Dari beberapa pendapat tersebut, peneliti mengintegrasikan dan menyimpulkan sehingga terbentuk indikator-indikator dalam penelitian yang akan dikembangkan menjadi instrumen untuk memperoleh data yang akurat di lapangan.

Dalam penelitian ini metode pengumpulan data yang digunakan adalah dengan menggunakan angket ( kuesioner) yang diberikan pada semua guru IPS MAN Se Kota Malang yang sudah sertifikasi. Data primer yang diambil adalah data tentang profesionalitas guru, pengembangan diri berkelanjutan dan kepuasan kerja. Sedangkan angket tentang kinerja guru diisi oleh Kepala Sekolah. Data Sekunder lainnya jumlah guru yang sudah sertifikasi/ identitas guru yang sudah sertifikasi. Skala pengukuran untuk data primer dengan menggunakan Skala likert. Pengujian data digunakan uji validitas dan reliabilitas. 


\section{HASIL PENELITIAN}

- Pengaruh Sertifikasi Guru terhadap Profesionalisme, Pengembangan Diri Berkelanjutan, dan Kepuasan Kerja Guru IPS MAN Malang Pasca Sertifikasi

Pada bagian ini akan dilakukan pengamatan terhadap jawaban guru menganai pertanyaan yang diajukan oleh peneliti dalam hal Profesionalisme, Pengembangan Diri Berkelanjutan, dan Kepuasan Kerja yang masing-masing terdiri dari 5 pertanyaan. Analisa yang dilakukan adalah dengan menggunakan statistik deskriptif yaitu distribusi frekuensi. Hasil analisa disajikan sebagai berikut.

a.1. Pengaruh Sertifikasi Guru terhadap Profesionalisme Guru IPS MAN Malang Pasca Sertifikasi

\section{Profesionalisme 1}

\begin{tabular}{|l|r|r|r|r|}
\hline & Frequency & Percent & Valid Percent & $\begin{array}{c}\text { Cumulative } \\
\text { Percent }\end{array}$ \\
\hline Valid Selalu & 10 & 100.0 & 100.0 & 100.0 \\
\hline
\end{tabular}

Berdasarkan tabel di atas mengenai "Sebagai guru berminat menyenangi mata pelajaran yang saya ajarkan, karena sesuai dengan ijazah yang saya miliki“, dapat diketahui bahwa dari 10 guru yang diberikan kuesioner terdapat 0 orang $(0 \%)$ yang menyatakan Tidak Tahu (TT), 0 orang $(0 \%)$ yang menyatakan Tidak Pernah (TP), 0 orang (0\%) yang menyatakan Jarang (JR), 0 orang (0\%) yang menyatakan Sering (SR), dan 10 orang (100\%) yang menyatakan Selalu (SL). Hal ini menunjukkan bahwa mayoritas guru yang diamati menyatakan Selalu melakukan mengenai pernyataan Profesionalisme yang ditanyakan.

\section{Profesionalisme 2}

\begin{tabular}{|l|r|r|r|r|}
\hline & Frequency & Percent & Valid Percent & Cumulative \\
& & & & Percent \\
\hline Valid Selalu & 10 & 100.0 & 100.0 & 100.0 \\
\hline
\end{tabular}

Berdasarkan tabel di atas mengenai "Senang dan antusias untuk mempelajari mata pelajaran yang saya ajarkan“, dapat diketahui bahwa dari 10 guru yang diberikan kuesioner 
terdapat 0 orang $(0 \%)$ yang menyatakan Tidak Tahu (TT), 0 orang $(0 \%)$ yang menyatakan Tidak Pernah (TP), 0 orang $(0 \%)$ yang menyatakan Jarang (JR), 0 orang (0\%) yang menyatakan Sering (SR), dan 10 orang (100\%) yang menyatakan Selalu (SL). Hal ini menunjukkan bahwa mayoritas guru yang diamati menyatakan Selalu melakukan mengenai pernyataan Profesionalisme yang ditanyakan.

Profesionalisme 3

\begin{tabular}{|r|r|r|r|r|}
\hline & Frequency & Percent & Valid Percent & \multicolumn{2}{c|}{$\begin{array}{c}\text { Cumulative } \\
\text { Percent }\end{array}$} \\
\hline Valid Jarang & 1 & 10.0 & 10.0 & 10.0 \\
Selalu & 4 & 40.0 & 40.0 & 50.0 \\
Total & 5 & 50.0 & 50.0 & 100.0 \\
& 10 & 100.0 & 100.0 & \\
\hline
\end{tabular}

Berdasarkan tabel di atas mengenai "Menyesuaikan materi pelajaran yang saya sajikan dengan kepustakaan/kemajuan IPTEK yang paling mutakhir", dapat diketahui bahwa dari 10 guru yang diberikan kuesioner terdapat 0 orang $(0 \%)$ yang menyatakan Tidak Tahu (TT), 0 orang $(0 \%)$ yang menyatakan Tidak Pernah (TP), 1 orang $(10 \%)$ yang menyatakan Jarang (JR), 4 orang (40\%) yang menyatakan Sering (SR), dan 5 orang (50\%) yang menyatakan Selalu (SL). Hal ini menunjukkan bahwa mayoritas guru yang diamati menyatakan Selalu melakukan mengenai pernyataan Profesionalisme yang ditanyakan.

Profesionalisme 4

\begin{tabular}{|l|r|r|r|r|}
\hline & Frequency & Percent & Valid Percent & $\begin{array}{c}\text { Cumulative } \\
\text { Percent }\end{array}$ \\
\hline Valid Sering & 6 & 60.0 & 60.0 & 60.0 \\
& 4 & 40.0 & 40.0 & 100.0 \\
\hline
\end{tabular}


Profesionalisme 4

\begin{tabular}{|r|r|r|r|r|}
\hline & Frequency & Percent & Valid Percent & $\begin{array}{c}\text { Cumulative } \\
\text { Percent }\end{array}$ \\
\hline Valid Sering & 6 & 60.0 & 60.0 & 60.0 \\
& 4 & 40.0 & 40.0 & 100.0 \\
Solalu & 10 & 100.0 & 100.0 & \\
\hline
\end{tabular}

Berdasarkan tabel di atas mengenai "Menulis dan menyiapkan secara jelas RPP sesuai dengan SKL yang ada“, dapat diketahui bahwa dari 10 guru yang diberikan kuesioner terdapat 0 orang $(0 \%)$ yang menyatakan Tidak Tahu (TT), 0 orang $(0 \%)$ yang menyatakan Tidak Pernah (TP), 0 orang $(0 \%)$ yang menyatakan Jarang (JR), 6 orang (60\%) yang menyatakan Sering (SR), dan 4 orang (40\%) yang menyatakan Selalu (SL). Hal ini menunjukkan bahwa mayoritas guru yang diamati menyatakan Sering melakukan mengenai pernyataan Profesionalisme yang ditanyakan.

Profesionalisme 5

\begin{tabular}{|r|r|r|r|r|}
\hline & Frequency & Percent & Valid Percent & \multicolumn{2}{c|}{$\begin{array}{c}\text { Cumulative } \\
\text { Percent }\end{array}$} \\
\hline Valid Jarang & 1 & 10.0 & 10.0 & 10.0 \\
Sering & 5 & 50.0 & 50.0 & 60.0 \\
Selalu & 4 & 40.0 & 40.0 & 100.0 \\
Total & 10 & 100.0 & 100.0 & \\
\hline
\end{tabular}

Berdasarkan tabel di atas mengenai "Menyiapkan hand out mata pelajaran", dapat diketahui bahwa dari 10 guru yang diberikan kuesioner terdapat 0 orang (0\%) yang menyatakan Tidak Tahu (TT), 0 orang (0\%) yang menyatakan Tidak Pernah (TP), 1 orang (10\%) yang menyatakan Jarang (JR), 5 orang (50\%) yang menyatakan Sering (SR), dan 4 
orang (40\%) yang menyatakan Selalu (SL). Hal ini menunjukkan bahwa mayoritas guru yang diamati menyatakan Sering melakukan mengenai pernyataan Profesionalisme yang ditanyakan.

\section{a.2. Pengaruh Sertifikasi Guru terhadap Pengembangan Diri Berkelanjutan Guru IPS MAN Malang Pasca Sertifikasi}

Pengembangan Diri Berkelanjutan1

\begin{tabular}{|r|r|r|r|r|}
\hline & Frequency & Percent & Valid Percent & \multicolumn{2}{c|}{$\begin{array}{c}\text { Cumulative } \\
\text { Percent }\end{array}$} \\
\hline Valid Jarang & 2 & 20.0 & 20.0 & 20.0 \\
Selalu & 6 & 60.0 & 60.0 & 80.0 \\
Total & 2 & 20.0 & 20.0 & 100.0 \\
& 10 & 100.0 & 100.0 & \\
\hline
\end{tabular}

Berdasarkan tabel di atas mengenai "Selalu mengikuti workshop kurikulum baik yang diadakan oleh sekolah atau di luar sekolah", dapat diketahui bahwa dari 10 guru yang diberikan kuesioner terdapat 0 orang $(0 \%)$ yang menyatakan Tidak Tahu (TT), 0 orang $(0 \%)$ yang menyatakan Tidak Pernah (TP), 2 orang (20\%) yang menyatakan Jarang (JR), 6 orang $(60 \%)$ yang menyatakan Sering (SR), dan 2 orang (20\%) yang menyatakan Selalu (SL). Hal ini menunjukkan bahwa mayoritas guru yang diamati menyatakan Sering melakukan mengenai pernyataan Pengembangan Diri Berkelanjutan yang ditanyakan.

Pengembangan Diri Berkelanjutan2

\begin{tabular}{|l|r|r|r|r|}
\hline & Frequency & Percent & Valid Percent & $\begin{array}{c}\text { Cumulative } \\
\text { Percent }\end{array}$ \\
\hline Valid Jarang & 1 & 10.0 & 10.0 & 10.0 \\
& 7 & 70.0 & 70.0 & 80.0 \\
\hline
\end{tabular}


Ni'matuz Zuhroh: Pengaruh Sertifikasi Guru...

\begin{tabular}{|r|r|r|r|r|}
\hline Selalu & 2 & 20.0 & 20.0 & 100.0 \\
& 10 & 100.0 & 100.0 & \\
\hline
\end{tabular}

Berdasarkan tabel di atas mengenai "Selalu menerapkan teori/prinsip/konsep yang saya jelaskan dalam pendekatan pemecahan masalah seperti pengalaman atau ilmu yang saya dapatkan dari pelatihan“, dapat diketahui bahwa dari 10 guru yang diberikan kuesioner terdapat 0 orang $(0 \%)$ yang menyatakan Tidak Tahu (TT), 0 orang $(0 \%)$ yang menyatakan Tidak Pernah (TP), 1 orang (10\%) yang menyatakan Jarang (JR), 7 orang (70\%) yang menyatakan Sering (SR), dan 2 orang (20\%) yang menyatakan Selalu (SL). Hal ini menunjukkan bahwa mayoritas guru yang diamati menyatakan Sering melakukan mengenai pernyataan Pengembangan Diri Berkelanjutan yang ditanyakan.

Pengembangan Diri Berkelanjutan 3

\begin{tabular}{|r|r|r|r|r|}
\hline & Frequency & Percent & Valid Percent & $\begin{array}{r}\text { Cumulative } \\
\text { Percent }\end{array}$ \\
\hline Valid Sering & 9 & 90.0 & 90.0 & 100.0 \\
Selalu & 1 & 10.0 & 10.0 & \\
Total & 10 & 100.0 & 100.0 & \\
\hline
\end{tabular}

Berdasarkan tabel di atas mengenai "Menggunakan bahan peraga sebagai alat pembelajaran dan audio visual“, dapat diketahui bahwa dari 10 guru yang diberikan kuesioner terdapat 0 orang $(0 \%)$ yang menyatakan Tidak Tahu (TT), 0 orang (0\%) yang menyatakan Tidak Pernah (TP), 0 orang (0\%) yang menyatakan Jarang (JR), 9 orang (90\%) yang menyatakan Sering (SR), dan 1 orang (10\%) yang menyatakan Selalu (SL). Hal ini menunjukkan bahwa mayoritas guru yang diamati menyatakan Sering melakukan mengenai pernyataan Pengembangan Diri Berkelanjutan yang ditanyakan.

\section{Pengembangan Diri Berkelanjutan4}


Ni'matuz Zuhroh: Pengaruh Sertifikasi Guru...

\begin{tabular}{|l|r|r|r|r|}
\hline & Frequency & Percent & Valid Percent & $\begin{array}{c}\text { Cumulative } \\
\text { Percent }\end{array}$ \\
\hline Valid Tidak Pernah & 1 & 10.0 & 10.0 & 10.0 \\
Jarang & 5 & 50.0 & 50.0 & 60.0 \\
Sering & 3 & 30.0 & 30.0 & 90.0 \\
Selalu & 1 & 10.0 & 10.0 & 100.0 \\
Total & 10 & 100.0 & 100.0 & \\
\hline
\end{tabular}

Berdasarkan tabel di atas mengenai "Menyampaikan orasi ilmiah", dapat diketahui bahwa dari 10 guru yang diberikan kuesioner terdapat 0 orang $(0 \%)$ yang menyatakan Tidak Tahu (TT), 1 orang (10\%) yang menyatakan Tidak Pernah (TP), 5 orang (50\%) yang menyatakan Jarang (JR), 3 orang (30\%) yang menyatakan Sering (SR), dan 1 orang (10\%) yang menyatakan Selalu (SL). Hal ini menunjukkan bahwa mayoritas guru yang diamati menyatakan Jarang melakukan mengenai pernyataan Pengembangan Diri Berkelanjutan yang ditanyakan.

Pengembangan Diri Berkelanjutan 5

\begin{tabular}{|r|r|r|r|r|}
\hline & Frequency & Percent & Valid Percent & \multicolumn{2}{c|}{$\begin{array}{c}\text { Cumulative } \\
\text { Percent }\end{array}$} \\
\hline Valid Jarang & 1 & 10.0 & 10.0 & 10.0 \\
Sering & 8 & 80.0 & 80.0 & 90.0 \\
Selalu & 1 & 10.0 & 10.0 & 100.0 \\
Total & 10 & 100.0 & 100.0 & \\
\hline
\end{tabular}

Berdasarkan tabel di atas mengenai "Selalu ingin mengembangkan potensi yang dimiliki baik dengan ikut serta pelatihan ataupun melanjutkan sekolah ke jenjang berikutnya“", dapat diketahui bahwa dari 10 guru yang diberikan kuesioner terdapat 0 orang 
(0\%) yang menyatakan Tidak Tahu (TT), 0 orang $(0 \%)$ yang menyatakan Tidak Pernah (TP), 1 orang (10\%) yang menyatakan Jarang (JR), 8 orang (80\%) yang menyatakan Sering (SR), dan 1 orang (10\%) yang menyatakan Selalu (SL). Hal ini menunjukkan bahwa mayoritas guru yang diamati menyatakan Sering melakukan mengenai pernyataan Pengembangan Diri Berkelanjutan yang ditanyakan.

\section{a.3. Pengaruh Sertifikasi Guru terhadap Kepuasan Kerja Guru IPS MAN Malang Pasca Sertifikasi}

Kepuasan Kinerja 1

\begin{tabular}{|r|r|r|r|r|}
\hline & Frequency & Percent & Valid Percent & $\begin{array}{c}\text { Cumulative } \\
\text { Percent }\end{array}$ \\
\hline Valid Jarang & 2 & 20.0 & 20.0 & 20.0 \\
Sering & 7 & 70.0 & 70.0 & 90.0 \\
Selalu & 1 & 10.0 & 10.0 & 100.0 \\
Total & 10 & 100.0 & 100.0 & \\
\hline
\end{tabular}

Berdasarkan tabel di atas mengenai "Memiliki prakarsa yang tinggi dalam rangka memajukan lembaga“, dapat diketahui bahwa dari 10 guru yang diberikan kuesioner terdapat 0 orang $(0 \%)$ yang menyatakan Tidak Tahu (TT), 0 orang $(0 \%)$ yang menyatakan Tidak Pernah (TP), 2 orang (20\%) yang menyatakan Jarang (JR), 7 orang (70\%) yang menyatakan Sering (SR), dan 1 orang (10\%) yang menyatakan Selalu (SL). Hal ini menunjukkan bahwa mayoritas guru yang diamati menyatakan Sering melakukan mengenai pernyataan Kepuasan Kinerja yang ditanyakan.

\section{Kepuasan Kinerja 2}

\begin{tabular}{|l|r|r|r|r|}
\hline & Frequency & Percent & Valid Percent & $\begin{array}{c}\text { Cumulative } \\
\text { Percent }\end{array}$ \\
\hline Valid Jarang & 2 & 20.0 & 20.0 & 20.0 \\
\hline
\end{tabular}


Ni'matuz Zuhroh: Pengaruh Sertifikasi Guru...

\begin{tabular}{|l|r|r|r|r|}
\hline Sering & 8 & 80.0 & 80.0 & 100.0 \\
\hline & 10 & 100.0 & 100.0 & \\
\hline
\end{tabular}

Berdasarkan tabel di atas mengenai "Menyelenggarakan pendidikan di laboraturium, teknologi pengajaran atau di alapangan“, dapat diketahui bahwa dari 10 guru yang diberikan kuesioner terdapat 0 orang $(0 \%)$ yang menyatakan Tidak Tahu (TT), 0 orang $(0 \%)$ yang menyatakan Tidak Pernah (TP), 2 orang (20\%) yang menyatakan Jarang (JR), 8 orang (80\%) yang menyatakan Sering (SR), dan 0 orang (0\%) yang menyatakan Selalu (SL). Hal ini menunjukkan bahwa mayoritas guru yang diamati menyatakan Sering melakukan mengenai pernyataan Kepuasan Kinerja yang ditanyakan.

\section{Kepuasan Kinerja 3}

\begin{tabular}{|l|r|r|r|r|}
\hline & Frequency & Percent & Valid Percent & $\begin{array}{c}\text { Cumulative } \\
\text { Percent }\end{array}$ \\
\hline Valid Jarang & 3 & 30.0 & 30.0 & 30.0 \\
Sering & 7 & 70.0 & 70.0 & 100.0 \\
& 10 & 100.0 & 100.0 & \\
\hline
\end{tabular}

Berdasarkan tabel di atas mengenai "Melaksanakan praktek lapangan", dapat diketahui bahwa dari 10 guru yang diberikan kuesioner terdapat 0 orang (0\%) yang menyatakan Tidak Tahu (TT), 0 orang (0\%) yang menyatakan Tidak Pernah (TP), 3 orang $(30 \%)$ yang menyatakan Jarang (JR), 7 orang (70\%) yang menyatakan Sering (SR), dan 0 orang $(0 \%)$ yang menyatakan Selalu (SL). Hal ini menunjukkan bahwa mayoritas guru yang diamati menyatakan Sering melakukan mengenai pernyataan Kepuasan Kinerja yang ditanyakan.

\section{Kepuasan Kinerja 4}

\begin{tabular}{|l|l|l|l|c|}
\hline & Frequency & Percent & Valid Percent & Cumulative \\
Percent
\end{tabular}




\begin{tabular}{|r|r|r|r|r|}
\hline Valid Jarang & 1 & 10.0 & 10.0 & 10.0 \\
& 8 & 80.0 & 80.0 & 90.0 \\
Sering & 1 & 10.0 & 10.0 & 100.0 \\
Selalu & 10 & 100.0 & 100.0 & \\
\hline
\end{tabular}

Berdasarkan tabel di atas mengenai "Melaksanakan pembelajaran / tutorial baik dalam kelas maupun di luar kelas secara aktif“, dapat diketahui bahwa dari 10 guru yang diberikan kuesioner terdapat 0 orang $(0 \%)$ yang menyatakan Tidak Tahu (TT), 0 orang $(0 \%)$ yang menyatakan Tidak Pernah (TP), 1 orang (10\%) yang menyatakan Jarang (JR), 8 orang (80\%) yang menyatakan Sering (SR), dan 1 orang (10\%) yang menyatakan Selalu (SL). Hal ini menunjukkan bahwa mayoritas guru yang diamati menyatakan Sering melakukan mengenai pernyataan Kepuasan Kinerja yang ditanyakan.

\section{Kepuasan Kinerja 5}

\begin{tabular}{|r|r|r|r|r|}
\hline & Frequency & Percent & Valid Percent & $\begin{array}{c}\text { Cumulative } \\
\text { Percent }\end{array}$ \\
\hline Valid Sering & 1 & 10.0 & 10.0 & 10.0 \\
Selalu & 9 & 90.0 & 90.0 & 100.0 \\
Total & 10 & 100.0 & 100.0 & \\
\hline
\end{tabular}

Berdasarkan tabel di atas mengenai "Memiliki kinerja yang baik walaupun tidak diawasi oleh kepala sekolah atau pimpinan dalam rangka memajukan lembaga“, dapat diketahui bahwa dari 10 guru yang diberikan kuesioner terdapat 0 orang (0\%) yang menyatakan Tidak Tahu (TT), 0 orang (0\%) yang menyatakan Tidak Pernah (TP), 0 orang (0\%) yang menyatakan Jarang (JR), 1 orang (10\%) yang menyatakan Sering (SR), dan 9 orang (90\%) yang menyatakan Selalu (SL). Hal ini menunjukkan bahwa mayoritas guru yang diamati menyatakan Selalu melakukan mengenai pernyataan Kepuasan Kinerja yang ditanyakan. 


\section{KESIMPULAN DAN SARAN}

Dari penjelasan diatas bahwa“"Pengaruh Sertifikasi Guru terhadap Profesionalisme, Pengembangan Diri Berkelanjutan, dan Kepuasan Kerja Guru IPS MAN Malang Pasca Sertifikasi”. Berpengaruh secara signifikan.

Dengan kesimpulan tersebut bukan berarti hasil penelitian ini menjadi hak paten, artinya sudah sempurna. Namun masih perlu ditindaklanjuti atau disempurnakan, sehingga akan lebih sempurna. Ada beberapa hal yang masih perlu dilakukan peembenahan.

Oleh karena itu, kritik dan saran yang membangun sangat kami harapkan dari semua pihak pemerhati, pelaksana pendidikan untuk kesempurnaan yang akhirnya dapat memberikan pencerahan pelaksanaan di tingkat sekolah.terutama pada MAN Se Kota Malang.

\section{DAFTAR PUSTAKA}

- Alma Buchari, 2009. Guru Profesional, Menguasai Metode dan Terampil Mengajar Bandung: Alfabeta.

- $\quad$ Luthan F.2006. Perilaku Organisasi edisi sepuluh. Terjemahan.Yogyakarta: Andi.

- Mahsunah D.dkk (2012) Kebijakan Pengembangan Profesi Guru. Materi Pendidikan dan Latihan Profesi Guru. Badan Pengembangan Sumber Daya Manusia Pendidikan dan Kebudayaan dan Penjaminan Mutu Pendidikan, Kementrian Pendidikan dan Kebudayaan.

- Mulyasa, 2011, Standar Kompetensi dan sertifikasi Guru. Bandung: Remaja Rosdakarya.

- Parwanto dan Wahyudin, 2005. Pengaruh Faktor-faktor Kepuasan Kerja terhadap Kinerja Karyawan Pusat Pendidikan Komputer Akutansi IMKA. UMS.

- Payong. M.R.2011. Sertifikasi Guru Konsep Dasar, Problematika dan Implementasinya. Jakarta: PT.Indeks.

- Peraturan Menteri Negara Pendayagunaan Aparatur Negara dan Reformasi Birokrasi No 16 tahun 2009 tentang Jabatan Fungsional, Guru dan Angka kreditnya (on line), (http; www.ac.id).

- Peraturan Menteri Pendidikan Nasional No.39 tahun 2009 tentang Pemenuhan beban kerja dan pengawas satuan pendidikan, (online), ( http;www.diknas.ac.id) 
- Peraturan Pemerintah Republik Indonesia No.41 tahun 2009 tentang Tunjangan Profesi Guru dan Dosen, Tunjangan Khusus Guru dan Dosen, serta Tunjangan Kehormatan Profesor, ( online), ( http;www.diknas.ac.id)

- Saud. U.S.2010. Pengembangan Profesi Guru. Bandung: Alfabeta.

- Saudagar, A. Dan Idrus A, 2009, Pengembangan Profesionalisme Guru, Jakarta. Gaung Persada.

- Sopiah, 2008. Perilaku Organisasional. Yogyakarta;Andi

- Sugiyono.2011. Metode Penelitian Kuantitatif dan Kualitatif dan R\&D. Bandung Alfabeta.

- Sukamto.2009. Pengembangan Profesi Guru secara berkesinambungan sebagai Strategi Nasional pendukung Sertifikasi Guru. ( online).

- $\quad$ Tim Dosen Fakultas Tarbiyah UIN Malang, 2006, buku PLPG, UIN Press

- Yamin. M.2009. Profesionalisasi Guru dan Implementasi KTSP. Jakarta; Gaung Persada Press.

- Yamin M dan Maisah, 2010. Standarisasi Kinerja Guru. Gaung Persada Press.

- Undang-undang Republik Indonesia No 20 tahun 2003 tentang Sistem Pendidikan Nasional; Jakarta: Sinar Grafika. 